\title{
Inhibitory Effect of Nigella Sativa Seeds and Curcumin on Hepatotoxicity Induced By Aflatoxin in Japanese Quails Associated With DNA Damage
}

Reham A. Abd-Elwahab ${ }^{* 1}$, Saleh S.Y. ${ }^{2}$, Ibrahim A. I ${ }^{3}$, Elramady R. A. ${ }^{4}$

${ }^{1,4}$ Department of Biochemistry, Animal Health Research Institute (AHRI), Mansoura, Egypt.

${ }^{2,3}$ Department of Biochemistry, Faculty of Vet. Medicine, Suez Canal University, Ismailia, Egypt.

\begin{abstract}
This study is aimed to investigate the adverse effects of Aflatoxin (AFs) on performances, immunity and some biochemical parameters in serum and tissues of Japanese quails as well as to evaluate the possible protective effects of Nigella sativa (NS) crushed seeds and Curcumin powders to overcome the adverse effects of AFs. A total 120 unsexed Japanese quails chicks were divided equally into 4 groups; control group (G1), AFs group $2.5 \mathrm{ppm}(\mathrm{G} 2)$, AFs $2.5 \mathrm{ppm}$ plus Nigella sativa $1.5 \%$ (G3) and AFs $2.5 \mathrm{ppm}$ plus Curcumin powders $400 \mathrm{mg} / \mathrm{kg}$ diet (G4) for one month of experiment. AFs induced hepatotoxicity and immunosuppressive revealed by significant decrease in B.W, total leukocytes count and lymphocytes percent, while increase in heterophils percent, it also induced a significant decrease in serum total protein, albumin and globulin, on the other hand significant increase in alanine aminotransferase (ALT) and aspartate aminotransferase (AST), significant decrease in superoxide dismutase (SOD) and reduced glutathione (GSH) activity, while significant increase in malonaladahyde activity (MDA) and also in DNA fragmentation. Treatment with NS and Curcumin produce significant increase in B.W, TLC and lymphocytes percent, while decrease in heterophils percent, significant increase in total protein, albumin and globulin, on the other hand significant decrease in ALT and AST, significant increase in SOD, GSH activity and significant decrease in MDA activity and significance decrease in DNA fragmentation. This study indicated that treatment with Nigella sativa and Curcumin improved the adverse effects of AFs on performances, immunity, some biochemical parameters in serum and tissues and also gave more protection for DNA from fragmentation.
\end{abstract}

Key words: quails, AFs, Nigella sativa, Curcumin, immunity. 
Introduction

Quails are considered very important that are used for eggs and meat (DAFF, 2013). The quail egg contains vitamins and antioxidants (Sahin et al., 2008), it has 3 to 4 times multi-nutritional content more than chicken eggs (Tunsaringkarn et al., 2013). Mycotoxins are poisonous substances produced by fungi, it's important to know that not every toxic substance synthesized by fungi is considered mycotoxin (Bennett

and Klich, 2003). Mycotoxicosis is a current problem faces the poultry farmers (Madheswaran et al., 2004; Ortatatli et al., 2005). The factors affecting mycotoxin production are including fungal species potential, substrate composition, the duration of fungal growth, moisture percent, temperature degree, and storage enviroment. Stress factors such as shortage of water, insect infestation, and other pests' attack can also enhance toxin production (Sanchis and Magan 2004; Milani, 2013). Consumption of contaminated diet with AFs causes serious problems to animal's health because it has severed toxic, carcinogenic and mutagenic effects on it (Ferreira et al., 2013). Reduction of AFs in contaminated diet applies by many methods. Although, none of them has any value (Diaz et al., 2002). AFs makes significant changes in serum biochemistry parameters are generally regarded as indicative of aflatoxicosis (Basmacioglu et al., 2005).

From the ancient times the medicinal plants and herbal remedies used in prevention and treatment of many diseases and disorders cure (Ashiq et al., 2014). Nigella sativa is an annual herbaceous plant; seeds are black in color and taste slightly bitter (Aljabre et al., 2005). The seeds of the plant are extensively used in traditional medicine in some countries, for the treatment of several diseases (Nostro et al., 2000).

NS seeds have many pharmacological properities as anticarcinogenic (Rooney and Ryan, 2005), antiulcer (Kanter et al., 2005), antibacterial (Morsi, 2000), antifungal (Khan et al., 2003), antiinflammatory, antipyretic and analgesic (Al-Ghamdi, 2001).

Curcumin structure (1, 7-Bis 4hydroxy-3-methoxy phenyl-1-6heptadiene-3, 5-dione) like diferuloylmethane was known Kazimierz Kostanecki, J. Miłobędzka and Wiktor Lampe (Shishodia et al., 2005).

The Aim of The present Work: This study was aimed to investigate the effect of AF on Japanese quail as follows: (1) Preparation of AFs using standard toxigenic strain of Aspergillus parasiticus. (2) Study the effect of AFs on the body weight and performance of aflatoxicated Japanese quails. (3) Estimation of the immunosuppressive effect on the 
cellular immunity. (4) Evaluation the effect of $N S$ and Curcumin as anti-mycotoxin on Japanese quails treated with $\mathrm{AF}$.

\section{Materials and methods}

Experimental birds

and management:

A total number of 120 , one- weekold apparent healthy unsexed Japanese quails obtained from Agricultural Technological Center, Faculty of Agriculture, Cairo University, Giza, Egypt. Chicks one-week- old were kept for one week for acclimatization at the Animal House of Veterinary Medicine then for 30 days of experiment. The chicks were randomly divided into four groups of average body weight (30.5g). Each treatment group contained 30 birds which were subdivided into three replicates, each of 10 chicks. According to (Hassan et al., 2003), chicks were housed in wire battery cages of $86 \mathrm{~L} \times 50 \mathrm{~W} \times 25 \mathrm{H}$ cm were equally partitioned into 3 pens $(29 \times 50 \times 25 \mathrm{~cm})$. The batteries were provided with feeders and drinker equipments, the chicks were allowed ad libitum access to feed and water. Ventilation and temperature $\left(22^{\circ} \mathrm{C}-31^{\circ} \mathrm{C}\right)$. Room were electrically heated and conditions of constant light were employed, provided 24 hours of lighting and checked three times daily for food, water and mortality.

\section{Basal experimental diet:}

Diet was formulated to meet the nutritional requirements as suggested by the (NRC, 1994), to contain 24\% CP and $2900 \mathrm{kcal}$ $\mathrm{ME} / \mathrm{kg}$. Fresh feed were mixed weekly.

\section{Standred toxigenic strains:}

Toxigenic strain of Aspergillus parasiticus NRRL 2999 (ATCC) from Animal Health Research Institute Aldoki (AHRI) (Mycology department. On Fresh potato dextrose agar medium (FPDA): It used to stimulate spore formation of the mould strain, it was prepared according to shotwell et al., (1966). Moldy rice was autoclaved, dried and ground to fine powder. AFs levels in rice powder were measured by HPLC method in the Mycotoxins Central Lab and Food Safety of the National Research Center. Milled rice was added to the basal diet to provide $2.5 \mathrm{mg} \mathrm{AF} / \mathrm{Kg}$ diet $(2500 \mathrm{ppb})$ according to Eraslan et al ., (2004).

Treatment

Nigella sativa seeds: it was purchased from Isis company, registration No: COAE-Proc. /Exp. 111. COAE: Accreditation Certificate No.: DAKKs.ZE-3307.00. It was added freshly crushed with blender every week to the feed in a dose rate $1.5 \%$ according to Tahan and Bayram, (2011).

Curcumin powder $\left(\mathrm{C}_{21} \mathrm{H}_{20} \mathrm{O}_{6}\right)$. It was purchased from research lab company imported from India Batch No.557A110713. It was added to the diet in a dose rate 400 $\mathrm{mg} / \mathrm{kg}$ diet according to Tarasub et al., (2012).

Sampling:- 
Every 10 days samples were taken from all groups by slaughtering 10 birds from each group for the measurement of cellular immunity, biochemical parameters and DNA fragmentation.

Blood sampling:- Two blood samples were collected in each slaughter; the first one was collected in EDTA tubes to prevent blood coagulation and used for determination of total leucocytic count according to the method described by Natt and Herrick, (1952). And differential leucocytic count was performed using the method described by Hoyer, (1993). The second blood sample was collected into a clean and dry screw capped centrifuge tubes without anticoagulant and left to clot at room temperature, then centrifugated at 3000 r.p.m for collection of clear serum. Sample used for the biochemical analysis of serum total protein, serum albumin, serum globulin and serum liver enzymes ALT and AST by commercial kits (Diamond, Egypt) according to methods described by Young, (1995) ; Rodkey, (1965) ; Doumas and Biggs, (1972) ; Murray, (1984), respectively.

Tissues sampling:-
Biochemical analysis: - After the quails were slaughtered liver tissues were washed with normal saline then divided into 2 parts and preserved at $-20^{\circ} \mathrm{C}$. The first part for determination of Superoxide dismutase (SOD), Reduced glutathione (GSH), and Malondialdhehyde (MDA) by commercial kits (Bio diagnostic, Egypt) according to methods described by Nishikimi et al., (1972) ; Beutler et al., (1963) ;

Satoh, (1978) respectively, the second part of tissues were sent to Animal Health Research Institute (AHRI). Egypt. for determination of percentage of DNA fragmentation according to Gibb et al., (1997). As in this formula:

$[\mathrm{OD}(\mathrm{S}) / \mathrm{OD}(\mathrm{S})+\mathrm{OD}(\mathrm{P})] \mathrm{X} 100=$ $\%$ Fragmented DNA

\section{Statistical analysis:}

All the data were expressed as Means \pm S.E. The statistical significance was evaluated by oneway analysis of variance (ANOVA) using SPSS, 18.0 software, 2011 and the individual comparisons were obtained by Duncan's multiple range test (DMRT). Values were considered statistically significant when $\mathrm{p} \leq 0.05$. 
Table (A): the components of Basal experimental diet

\begin{tabular}{|c|c|}
\hline Ingredient & Concentration (kg/100kg diet) \\
\hline Ground yellow corn & 55.780 \\
\hline Soya bean meal & 31.960 \\
\hline Fish meal & 1.000 \\
\hline Corn gluten & 7.450 \\
\hline Bran & 1.000 \\
\hline DicalciumPhosphate(22\%Ca\&19\%P) & 0.710 \\
\hline Limeston (38\% Ca) & 1.300 \\
\hline Lysine (purity 98\%) & 0.170 \\
\hline DL - Methionine (purity 98\%) & 0.070 \\
\hline Iodized sodium chloride & 0.300 \\
\hline Mineral \& Vitamin premix & 0.300 \\
\hline
\end{tabular}

Table (B): HPLC results by National Research Center: according to Nabney and Nesbit (1965)

\begin{tabular}{|c|c|c|c|c|c|}
\hline \multirow{2}{*}{ Sample } & \multicolumn{5}{|c|}{ AFs (mg/kg) } \\
\cline { 2 - 6 } & B1 & B2 & G1 & G2 & Total \\
\hline AFs level in rice & 4.65 & 0.02 & 0.08 & 0.06 & $4.81 \mathrm{ppm}$ \\
\hline
\end{tabular}

Table (c): Experimental Design:

\begin{tabular}{|c|c|c|c|c|c|c|}
\hline Group & $\begin{array}{l}\text { No of } \\
\text { quails }\end{array}$ & $\begin{array}{c}\text { Age of } \\
\text { quails/week }\end{array}$ & $\begin{array}{l}\text { AFs } \\
2.5 \\
\mathbf{p p m}\end{array}$ & $\begin{array}{c}N S \\
1.5 \%\end{array}$ & $\begin{array}{c}\text { Curcumin } \\
\text { 400mg/kg/diet }\end{array}$ & $\underset{t}{\substack{\text { Time of } \\
\text { experimen }}}$ \\
\hline \multirow{3}{*}{$G 1$} & 10 & \multirow{3}{*}{2} & \multirow{3}{*}{-} & \multirow{3}{*}{ - } & \multirow{3}{*}{-} & 10 days \\
\hline & 10 & & & & & 20 days \\
\hline & 10 & & & & & 30 days \\
\hline \multirow{3}{*}{$G 2$} & 10 & \multirow{3}{*}{2} & \multirow{3}{*}{+} & \multirow{3}{*}{-} & \multirow{3}{*}{-} & 10 days \\
\hline & 10 & & & & & 20 days \\
\hline & 10 & & & & & 30 days \\
\hline \multirow{3}{*}{ G3 } & 10 & \multirow{3}{*}{2} & \multirow{3}{*}{+} & \multirow{3}{*}{+} & \multirow{3}{*}{-} & 10 days \\
\hline & 10 & & & & & 20 days \\
\hline & 10 & & & & & 30 days \\
\hline \multirow{3}{*}{ G4 } & 10 & \multirow{3}{*}{2} & \multirow{3}{*}{+} & \multirow{3}{*}{-} & \multirow{3}{*}{+} & 10 days \\
\hline & 10 & & & & & 20 days \\
\hline & 10 & & & & & 30 days \\
\hline Total & 120 & & & & & 30 days \\
\hline
\end{tabular}


Table keys: $\quad+=$ treated $\quad-=$ non treated

G1: control-ve group G2: AFs group G3: AFs $+N S$ group G4: AFs + Curcumin group

\section{Results:}

Table (1) showed that G2 which received $\mathrm{AF}$ in a dose $2.5 \mathrm{ppm}$ was significant $(\mathrm{P} \leq 0.05)$ decrease in body weight when compared to G1 after $10,20 \& 30$ days, Also total leucocytic counts was significantly $(\mathrm{P} \leq 0.05)$ decreased lymphocyte percent, while heterophils percent was significantly $(\mathrm{P} \leq \quad 0.05)$ increased. Table (1) showed that G3 and G4 were statistically significant $(\mathrm{P} \leq 0.05)$ increase in body weight when compared to G2 after 10, 20 \& 30 days, G3 significantly increased TLC and lymphocyte percent, while decrease heterophils percent than $\mathrm{G} \mid 2$, also $\mathrm{G} 4$ induced non significance changes in TLC and lymphocytes percent after 10 days but, showed significant $(\mathrm{P} \leq$ 0.05 ) increase when compared to G2 after $20 \& 30$ days, on the other hand G4 showed non significance changes after 20 days but, shows significant $(\mathrm{P} \leq$ 0.05) decrease heterophils percent at when compared to $\mathrm{G} 2$ after $10 \& 30$ days. Table (2) demonstrated that G2 was significant $(\mathrm{P} \leq 0.05)$ decrease in total protein, albumin and globulin when compared to G1 after 10, 20 \& 30 days, while ALT and AST was significant $(\mathrm{P} \leq 0.05)$ increase when compared to G1 after 10, 20 \& 30 days. Also Table (2) showed that $\mathrm{G} 3$ was significant $(\mathrm{P} \leq 0.05)$ increase in total protein and albumin when compared to $\mathrm{G} 2$ after 10, 20 \& 30 days. But G3 was non significance altered after $10 \& 20$ days although showed significant $(\mathrm{P} \leq 0.05)$ increase in globulin when compared to G2 after 30 days. However $\mathrm{G} 3$ had significant $(\mathrm{P} \leq$ 0.05) decrease in ALT and AST when compared to G2 after 10, 20 \& 30 days. Moreover Table (2) showed that G4 was non significance changes in total protein and albumin after $10 \& 30$ days but, shows significant $(\mathrm{P} \leq 0.05)$ increase in total protein and albumin than G2 after 20 days, however G4 induced non significance changes in globulin when compared to $\mathrm{G} 2$ after $10,20 \& 30$ days. However G4 was significant $(\mathrm{P} \leq 0.05)$ decrease in ALT when compared to G2 after $10,20 \& 30$ days, while G4 had non significance changes after 10 days in AST but, shows significant $(\mathrm{P} \leq$ 0.05) decrease in AST when compared to $\mathrm{G} 2$ after $20 \& 30$ days. Table (3) demonstrated that the G2 was significant $(\mathrm{P} \leq 0.05)$ decrease in SOD and GSH in liver tissues when compared to G1 after 10, 20 \& 30 days, However the G2 was significant $(\mathrm{P} \leq 0.05)$ increase in MDA activity in liver tissues homogenate when compared with G1. Table (3) showed that G3 and G4 were significant $(\mathrm{P} \leq 0.05)$ increase in SOD and GSH activity when compared to G2 after 10, 20 
\& 30 days, while that G3 and G4 were significant $(\mathrm{P} \leq 0.05)$ decrease in MDA when compared to G2 after $10,20 \& 30$ days Table (3) \& Fig. (1) showed that there were no significance changes in DNA fragmentation appeared in G1, G2, G3 and G4. DNA fragmentation percentage when compared to G1 induced significant $(\mathrm{P} \leq 0.05)$ decrease in DNA fragmentation when compared to G2 after $20 \& 30$ days of experiment.

Table (1): Effect of dietary AFs on body weight changes (in grams), TLC, Lymphocytes percent and Heterophils percent of quails in control and experimental quails:

\begin{tabular}{|c|c|c|c|c|c|}
\hline \multicolumn{2}{|c|}{ Groups } & $\begin{array}{c}\text { Control -ve } \\
\text { (G1) }\end{array}$ & AFs (G2) & $\begin{array}{c}\text { AFs+ NS } \\
\text { (G3) }\end{array}$ & $\begin{array}{c}\text { AFs }+ \text { Cur } \\
\text { (G4) }\end{array}$ \\
\hline \multirow{2}{*}{ 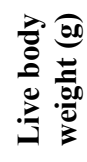 } & Initial & $80.56 \pm 4.38^{\mathrm{a}}$ & $80.00 \pm 3.75^{\mathrm{a}}$ & $80.80 \pm 3.91^{\mathrm{a}}$ & $80.74 \pm 4.22^{\mathrm{a}}$ \\
\hline & Final & $264.00 \pm 7.65^{\mathrm{a}}$ & $180.00 \pm 6.52^{\mathrm{d}}$ & $240.00 \pm 4.74^{\mathrm{b}}$ & $212.00 \pm 6.04^{\mathrm{c}}$ \\
\hline \multirow{3}{*}{ 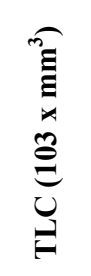 } & 10 days & $24.60 \pm 0.92^{\mathrm{a}}$ & $17.20 \pm 1.50^{\mathrm{b}}$ & $21.60 \pm 0.81^{\mathrm{a}}$ & $18.00 \pm 0.71^{\mathrm{b}}$ \\
\hline & 20 days & $32.00 \pm 0.70^{\mathrm{a}}$ & $21.00 \pm 1.18^{\mathrm{c}}$ & $31.80 \pm 1.15^{\mathrm{a}}$ & $25.60 \pm 1.40^{\mathrm{b}}$ \\
\hline & 30 days & $35.40 \pm 1.80^{\mathrm{a}}$ & $18.20 \pm 2.00^{\mathrm{c}}$ & $36.20 \pm 1.20^{\mathrm{a}}$ & $27.00 \pm 0.83^{\mathrm{b}}$ \\
\hline \multirow{3}{*}{ 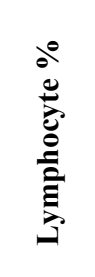 } & 10 days & $57.00 \pm 1.14^{\mathrm{a}}$ & $47.40 \pm 1.07^{\mathrm{b}}$ & $55.40 \pm 2.15^{\mathrm{a}}$ & $47.40 \pm 1.88^{\mathrm{b}}$ \\
\hline & 20 days & $58.00 \pm 1.26^{\mathrm{a}}$ & $47.60 \pm 0.74^{\mathrm{c}}$ & $57.80 \pm 0.86^{\mathrm{a}}$ & $51.20 \pm 0.85^{\mathrm{b}}$ \\
\hline & 30 days & $60.20 \pm 0.37^{\mathrm{a}}$ & $46.00 \pm 0.89^{d}$ & $56.80 \pm 0.96^{\mathrm{b}}$ & $52.80 \pm 1.28^{\mathrm{c}}$ \\
\hline \multirow{3}{*}{ 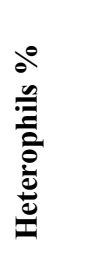 } & 10 days & $34.40 \pm 1.22^{\mathrm{c}}$ & $42.20 \pm 0.86^{\mathrm{a}}$ & $35.00 \pm 0.71^{\mathrm{bc}}$ & $37.10 \pm 0.71^{\mathrm{b}}$ \\
\hline & 20 days & $35.18 \pm 1.32^{\mathrm{b}}$ & $46.80 \pm 0.97^{\mathrm{a}}$ & $36.40 \pm 0.93^{b}$ & $43.20 \pm 1.66^{\mathrm{a}}$ \\
\hline & 30 days & $32.60 \pm 0.81^{\mathrm{d}}$ & $52.00 \pm 1.41^{\mathrm{a}}$ & $37.00 \pm 0.71^{\mathrm{c}}$ & $41.00 \pm 1.16^{\mathrm{b}}$ \\
\hline
\end{tabular}

Values are means \pm standard error (SE). Means within the same row with different superscripts are significantly different $(P \leq 0.05)$. 
Table (2): Effect of dietary AFs on [Tp, Albumin, Globulin, ALT and AST] in control and experimental quails:

\begin{tabular}{|c|c|c|c|c|c|}
\hline \multicolumn{2}{|c|}{ Groups } & Control -ve (G1) & AFs (G2) & $\begin{array}{c}\text { AFs+ NS } \\
\text { (G3) }\end{array}$ & $\begin{array}{c}\text { AFs+ Cur } \\
\text { (G4) }\end{array}$ \\
\hline \multirow{3}{*}{$\hat{\theta} \hat{\theta}$} & 10 days & $3.17 \pm 0.15^{\mathrm{a}}$ & $2.06 \pm 0.01^{\mathrm{c}}$ & $2.50 \pm 0.20^{\mathrm{b}}$ & $2.26 \pm 0.09^{b c}$ \\
\hline & 20 days & $4.50 \pm 0.16^{\mathrm{a}}$ & $3.23 \pm 0.06^{\mathrm{c}}$ & $3.89 \pm 0.22^{b}$ & $3.70 \pm 0.08^{b}$ \\
\hline & 30 days & $4.99 \pm 0.23^{\mathrm{a}}$ & $3.01 \pm 0.11^{\mathrm{c}}$ & $3.70 \pm 0.08^{b}$ & $3.27 \pm 0.25^{\mathrm{c}}$ \\
\hline \multirow{3}{*}{ 吾 } & 10 days & $1.74 \pm 0.06^{\mathrm{a}}$ & $1.22 \pm 0.08^{b}$ & $1.67 \pm 0.05^{\mathrm{a}}$ & $1.18 \pm 0.92^{b}$ \\
\hline & 20 days & $1.88 \pm 0.03^{\mathrm{a}}$ & $1.46 \pm 0.02^{\mathrm{d}}$ & $1.74 \pm 0.02^{b}$ & $1.56 \pm 0.02^{\mathrm{c}}$ \\
\hline & 30 days & $2.05 \pm 0.05^{\mathrm{a}}$ & $1.53 \pm 0.15^{\mathrm{c}}$ & $1.90 \pm 0.06^{\mathrm{ab}}$ & $1.69 \pm 0.05^{\mathrm{bc}}$ \\
\hline \multirow{3}{*}{ 产 } & 10 days & $1.44 \pm 0.21^{\mathrm{a}}$ & $0.84 \pm 0.07^{b}$ & $0.82 \pm 0.04^{b}$ & $1.08 \pm 0.37^{\mathrm{ab}}$ \\
\hline & 20 days & $2.6 \pm 0.18^{\mathrm{a}}$ & $1.78 \pm 0.07^{\mathrm{b}}$ & $2.00 \pm 0.21^{\mathrm{b}}$ & $2.14 \pm 0.06^{b}$ \\
\hline & 30 days & $2.94 \pm 0.23^{\mathrm{a}}$ & $1.48 \pm 0.21^{\mathrm{b}}$ & $2.40 \pm 0.08^{\mathrm{a}}$ & $1.58 \pm 0.24^{\mathrm{b}}$ \\
\hline \multirow{3}{*}{ 点 } & 10 days & $15.82 \pm 0.34^{\mathrm{c}}$ & $22.53 \pm 1.07^{\mathrm{a}}$ & $16.80 \pm 0.28^{\mathrm{bc}}$ & $18.31 \pm 0.97^{\mathrm{b}}$ \\
\hline & 20 days & $21.76 \pm 4.42^{\mathrm{c}}$ & $40.92 \pm 0.46^{\mathrm{a}}$ & $23.69 \pm 1.4^{\mathrm{c}}$ & $32.49 \pm 2.40^{\mathrm{b}}$ \\
\hline & 30 days & $18.84 \pm 0.56^{\mathrm{c}}$ & $65.80 \pm 5.43^{\mathrm{a}}$ & $33.98 \pm 1.83^{\mathrm{b}}$ & $41.81 \pm 0.81^{\mathrm{b}}$ \\
\hline \multirow{3}{*}{$\begin{array}{l}\text { AST } \\
(\mathbf{U} / \mathbf{l})\end{array}$} & 10 days & $165.95 \pm 2.08^{b}$ & $187.69 \pm 2.64^{\mathrm{a}}$ & $169.23 \pm 3.18^{b}$ & $181.58 \pm 2.78^{\mathrm{a}}$ \\
\hline & 20 days & $186.19 \pm 0.60^{\mathrm{d}}$ & $264.39 \pm 5.07^{\mathrm{a}}$ & $218.30 \pm 2.85^{\mathrm{c}}$ & $229.43 \pm 4.02^{b}$ \\
\hline & 30 days & $193.06 \pm 2.03^{\mathrm{d}}$ & $320.16 \pm 5.25^{\mathrm{a}}$ & $230.01 \pm 1.19^{c}$ & $241.76 \pm 3.65^{b}$ \\
\hline
\end{tabular}

Values are means \pm standard error (SE).

Means within the same row with different superscripts are significantly different $(P \leq 0.05)$.

Table (3): Effect of dietary AF on [tissue concentration of SOD activity, GSH activity, MDA and DNA fragmentation] of quails in control and experimental quails:

\begin{tabular}{|c|c|c|c|c|c|}
\hline & & Control -ve (G1) & AF (G2) & AF+ NS (G3) & $\mathrm{AF}+\mathrm{Cur}$ (G4) \\
\hline \multirow{3}{*}{ Oิ } & 10 days & $12.25 \pm 0.26^{\mathrm{a}}$ & $7.5 \pm 0.08^{d}$ & $10.26 \pm 0.08^{b}$ & $8.92 \pm 0.16^{\mathrm{c}}$ \\
\hline & 20 days & $14.29 \pm 0.40^{\mathrm{a}}$ & $6.30 \pm 0.10^{\mathrm{d}}$ & $11.70 \pm 0.32^{b}$ & $10.59 \pm 0.31^{\mathrm{c}}$ \\
\hline & 30 days & $15.38 \pm 0.24^{\mathrm{a}}$ & $4.36 \pm 0.48^{\mathrm{d}}$ & $13.27 \pm 0.47^{\mathrm{b}}$ & $11.59 \pm 0.24^{\mathrm{c}}$ \\
\hline \multirow{3}{*}{ 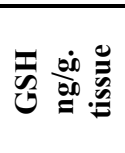 } & 10 days & $4.65 \pm 0.07^{\mathrm{a}}$ & $1.71 \pm 0.12^{\mathrm{d}}$ & $3.49 \pm 0.12^{b}$ & $2.85 \pm 0.17^{\mathrm{c}}$ \\
\hline & 20 days & $8.34 \pm 0.51^{\mathrm{a}}$ & $0.99 \pm 0.02^{\mathrm{d}}$ & $6.10 \pm 0.08^{b}$ & $4.73 \pm 0.24^{\mathrm{c}}$ \\
\hline & 30 days & $8.88 \pm 0.15^{\mathrm{a}}$ & $0.91 \pm 0.03^{\mathrm{d}}$ & $7.59 \pm 0.39^{b}$ & $5.64 \pm 0.11^{\mathrm{c}}$ \\
\hline \multirow{3}{*}{ 鹿总总 } & 10 days & $27.49 \pm 1.06^{\mathrm{c}}$ & $58.25 \pm 5.46^{\mathrm{a}}$ & $33.87 \pm 1.6^{b c}$ & $42.26 \pm 2.06^{b}$ \\
\hline & 20 days & $35.62 \pm 1.25^{\mathrm{d}}$ & $109.31 \pm 3.11^{\mathrm{a}}$ & $61.49 \pm 3.17^{\mathrm{c}}$ & $86.13 \pm 3.9^{b}$ \\
\hline & 30 days & $40.95 \pm 1.10^{\mathrm{d}}$ & $144.29 \pm 4.91^{\mathrm{a}}$ & $69.17 \pm 4.71^{\mathrm{c}}$ & $94.05 \pm 4.64^{\mathrm{a}}$ \\
\hline \multirow{3}{*}{ 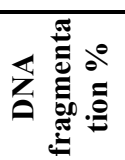 } & 10 days & $0.00 \pm 0.00^{\mathrm{a}}$ & $0.00 \pm 0.00^{\mathrm{a}}$ & $0.00 \pm 0.00^{\mathrm{a}}$ & $0.00 \pm 0.00^{\mathrm{a}}$ \\
\hline & 20 days & $4.23 \pm 0.03^{\mathrm{d}}$ & $19.77 \pm 0.63^{\mathrm{a}}$ & $7.37 \pm 0.60^{\mathrm{c}}$ & $11.13 \pm 0.16^{\mathrm{b}}$ \\
\hline & 30 days & $5.50 \pm 0.28^{\mathrm{d}}$ & $46.32 \pm 1.38^{\mathrm{a}}$ & $11.13 \pm 0.16^{\mathrm{c}}$ & $18.33 \pm 0.66^{\mathrm{b}}$ \\
\hline
\end{tabular}

Values are means \pm standard error (SE).

Means within the same row with different superscripts are significantly different $(\mathrm{P} \leq 0.05)$. 


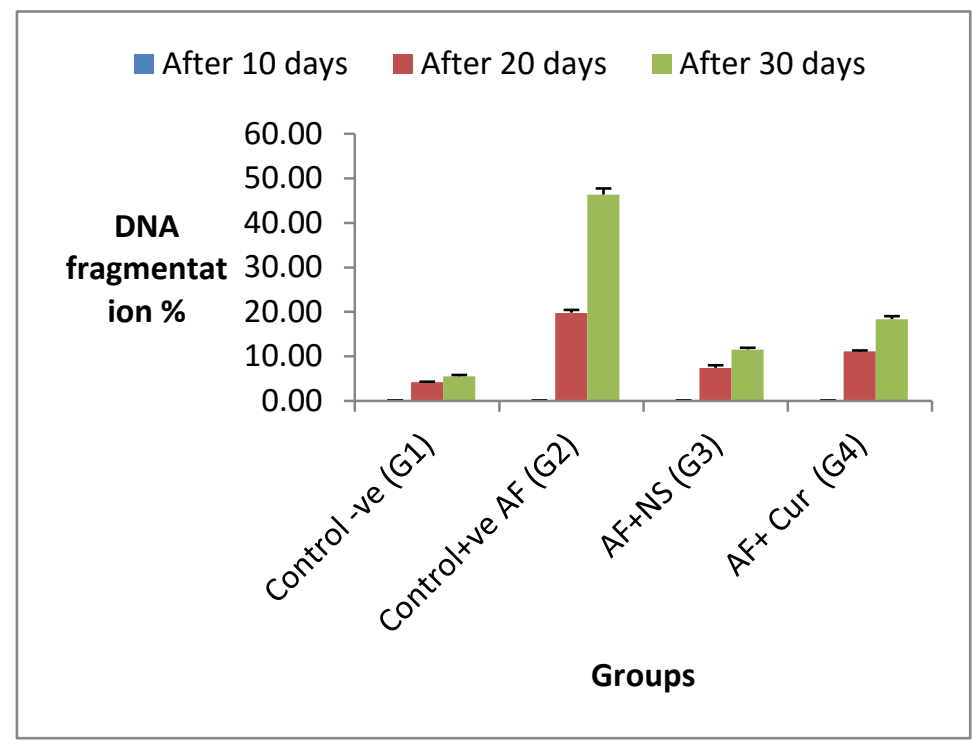

Fig. (1): Measurement of DNA fragmentation percentage in the liver tissues of quails.

\section{Disscussion}

AFs eradication from animal diets and feed stuffs considers a major problem worldwide so there is a great need to create new technological techniques for its removal from diets (Williams et al., 2004). Serious diseases caused by AFs in animals lead to severe economic losses and death sometimes (Mariam et al., 2013). Many methods were used for detoxification of AFs include physical, chemical and biological methods. In our experiments we used medicinal plants like Nigella sativa and Curcumin for control of AFs.

Concerning this study, G2 was significant $(\mathrm{P} \leq 0.05)$ decrease in body weight at after $10,20 \& 30$ days Table (1), these results were in agreement with the findings of Shehata et al., (2009). It might be due to that glutathione enzymes are utilized in process of detoxification to form methionine and cysteine, so the metabolic availability of methionine decrease and lead to poor feed efficiency and low growth rate (Devegowda et al., 1998).

According to our study which showed that $\mathrm{G} 2$ was significant $(\mathrm{P} \leq$ $0.05)$ decrease in total leucocytic count (TLC) and lymphocyte percent, while significant $(\mathrm{P} \leq 0.05)$ increase in heterophils percent after 10, $20 \& 30$ days Table (1), these results come in accordance with results of Mohapatra et al., (2011); Selim et al., (2014). Chamanza et al., (1999) and Bals, (2000). 
Reported that the recruitment and migration mechanisms involved in cellular immunity are affected by AFs. Communication between cells of the immune system and innate responses frequently require different proteins in blood, depression of cellular immunity in AFs contaminated animals may be due to decrease of protein level in serum in affected poultry, especially the globulins level which antibodies are belonged (Nazar et al., 2012).

In the present study, G2 was significant $(P \leq 0.05)$ decrease in total protein, albumin and globulin after $10,20 \& 30$ days Table (2), these finding is supported by Rosa et al., (2001) ; El-Sayed and Khalil, (2009) ; Mohapatra et al., (2011). AFs adducts binds to macromolecules of liver cells which in turn causes alterations in protein synthesis and cellular integrity, also lead to decrease of serum total protein and albumin (Jindal et al., 1994; Abo-Norag et al., 1995). However, depletion of globulin is due to the toxicity of hemopoietic plus lymphocytolysis (Sahoo et al., 2001).

For the present study, G2 was significant $(P \leq 0.05)$ increase in ALT and AST after $10,20 \& 30$ days Table (2), these results are in agreement with Amiridumari et al., (2013) ; Selim et al., (2014). AST and ALT are present in the cytosol of the hepatocytes, their elevation in the blood stream means that AFs cause severe destruction inside the hepatocytes and mitochondrial (Mathuria and Verma, 2008).

Concerning this study, the G2 was significant $(\mathrm{P} \leq 0.05)$ decrease in SOD, GSH activity in liver tissues after 10, $20 \& 30$ days Table (3), these results correlate well with (Mohamed et al., 2014; Naaz et al., 2007; Karabacak et al., 2015), with significant increase in hepatic MDA activity in liver tissues homogenate when compared with control group Table (3), these results are in accordance with (Naaz et al., 2007; Wang et al., 2013; Eraslan et al., 2005). During the metabolism of AFs by cytochrome p450 inside cells the reactive oxygen species (ROS) generate as super oxide anion, hydroxyl radical and $\mathrm{H}_{2} \mathrm{O}_{2}$ (Josephy, 1997; Preetha et al., 2006). SOD, an antioxidant enzyme is considered as the first and most important defense line against oxidative stress by catalyzing the conversion of superoxide anions or the active oxygen radical, produced in different stages of aerobic metabolism (Yamakura and Fujimura, 1998), to $2(\mathrm{O} 2)+\mathrm{H} 2 \mathrm{O} 2$ then catalase and glutathione peroxidase turn it into $\mathrm{H}_{2} \mathrm{O}$ (Afonso et al., 2007). GSH plays an important role in the antioxidant system of the body. It maintains the normal structure and function of the cells via a redox and detoxification reaction (El-Bahr, 2014). Eraslan et al., (2005) explained that the decline in SOD enzyme activity observed upon administration of high doses of AFs may be related to 
the consumption of highly active components during conversion into $\mathrm{H}_{2} \mathrm{O}_{2}$ due to the effect of AFs. That indicated the failure of antioxidant defense system to overcome the influx of ROS induced by AFs toxicity (Piner and Üner, 2012). Determination of MDA by thiobarbituric acid is used as in index of the extend of lipid peroxidation (Andallu and Varadacharyulu, 2003). The cytotoxic nature of AFs may be the underlying reason for the increase in MDA level (Eraslan et al., 2005). The significant reduction in the activities of antioxidant enzyme SOD and non-enzymatic antioxidant system (GSH) in aflatoxin treated group as compared to the control group could be responsible for increased TBARS levels observed during aflatoxininduced hepatic damage (Choudhary and Verma, 2005).

In this study, non-significant changes in DNA fragmentation appeared in G1, G2, G3 or G4 after 10 days of experiment Table (3) and Fig. (1), in the other hand, G2 was significant $(\mathrm{P} \leq 0.05)$ increase in DNA fragmentation percentage than G1 after 20 \& 30 days of experiment Table (3) and Fig. (1), these results were also confirmed by (Eshak et al., 2013). AFs oxidase by the oxidase system to many hydroxylated metabolites and to AFBs 8, 9 epoxide that binds to mitochondrial DNA lead to formation of AFB1-DNA adducts which indicated its genotoxicity
(Busby and Wogan, 1984) and disturbs DNA replication causing genetic alteration (Preston and Williams, 2005). The favorable binding formation is with guanine lead to formation of AFB1-N-7 guanine adduct which is the cause of mutagenesis in AF quails (Kallio and Lahdetie, 1997). This interaction of AFs can be with the total genomic DNA (Choy, 1993). This can result in small to large changes in genomic DNA including micronuclei and DNA fragmentation (Faridha et al., 2006).

The result of these study showed that $G 3$ and $\mathrm{G} 4$ were significant $(\mathrm{P} \leq$ 0.05) increase in body weight Table (1), these results correlate well with other reports Zaki et al., (2011); Sharma et al., (2011). Lee et al., (2003) reported that NS stimulate the enzymes of digestive as lipase and amylase beside mucosal secretion of intestine, these secretion are needed to enhance the digestion, to remove the pathogens adhesion and to establish the environmental media in intestine which the microorganisms balance are needed, so it improve the broilers performance by increasing the absorption and digestion of intestinal nutrients. Phenolic contents present in NS decrease the numbers of gut pathogens, so decreasing the loss of nutrients (Nasir and Grashorn, 2010). Abdel-Wahhab and Aly, (2005) Reported in NS groups showed improvement of all hematological 
and biochemical parameters towards the normal values of the controls thus improve the body performance and thus increase the body weight. Sharma et al., (2011), who explained that the coadministration with Curcumin improve bodyweight in comparison to AFB1 treated mice. It's suggested that antioxidant protection by Curcumin that is known to inhibit the biotransformation of AFB1 to aflatoxicol in liver (Lee and Shibamoto, 2001).

In the current study, G3 was significantly $(\mathrm{P} \leq 0.05)$ increased in total leucocytic counts and lymphocyte percent Table (1) also it significantly $(\mathrm{P} \leq 0.05)$ decreased in heterophils percent days Table (1), these results are confirmed with Abdel-Wahhab and Aly, (2005) ; Sharma et al., (2011) and for G4 (Asgary et al., 2012; Mahmoud, 2013). NS prevents the AFs damage from its oxidation as the lipid peroxidation including in numerous diseases like cancer and immunosuppression diseases (Lee and Shibamoto, 2001).

From the present study, it is evident that Curcumin may stabilize the cell membrane and restore various blood variables. The lower and higher levels of Curcumin increased both erythrocyte and total leukocyte count. Antony et al., (1999) proved that Curcumin has immunestimulating activity on animals by increasing the numbers of WBCs. The significance elevation in total protein, albumin and globulin in G3
Table (2) are supported with the other Shehata et al., (2009) ; Ayoub et al., (2011). The inhibitory effect of Nigella sativa on AF production ability of Aspergillus spp. might be related to several components known to have biological activities, such as $\alpha$ pinene and thymol and high phenolic content (Maraqa et al., 2007), this finding might be due to the antioxidant effect of Nigella sativa. These observations are agreed with that of (Al-Gaby, 1998) who used Nigella cake protein as feed supplement. Nigella sativa crushed seeds (Le et al., 2004). The increase in plasma albumin and globulin which acts as an indicator of immune response and source of antibody from feeding broilers chicks rations contain $2.5 \%$ crushed NS may be attributed to the immune-stimulant effects of NS (El-Ghammry et al., 2002). The positive effect of Curcumin powder on serum values (total protein and albumin) Table (2) demonstrated their ameliorative effect against AFs, with Curcumin providing antioxidant protection decreasing the amount of AFB1 absorbed (Gowda et al., 2008). Biosynthesis and secretion of serum protein becomes normalized (Mathuria and Verma, 2008).

In the present work, the G3 was significantly $(\mathrm{P} \leq 0.05)$ decreased in ALT and AST Table (2), these results are in agreement with $A$ youb et al., (2011); Nili-Ahmadabadi et al., (2011). The protective effects of 
NS oil may be due to the radical scavenging activity of its components, whereas the protective effects of S. aromaticum oil may be due to the phenolic compounds present in the oil that decrease the formation of aflatoxin B1 epoxides by the inhibition of CYP450 enzymes and increase the ability of liver microsomes to catalyse aflatoxin-glutathione conjugation. Consequently, NS is quite useful and reasonable in the treatment of aflatoxicosis (Abdel-Wahhab and Aly, 2005). Concerning the present study, the positive results of Curcumin treated group G4 on decreasing ALT and AST, Similar results have been reported by (Trivedi, 1999). El-Agamy, (2010) Curcumin showed significant hepatoprotective activity by lowering the levels of serum marker enzymes ALT \& AST. Treatment with Curcumin almost completely abolished the increase of serum ALT activity and decreased AST activity suggesting that Curcumin could effectively inhibit AFB1induced liver cell injury.

the present study showed that G3 significantly $(\mathrm{P} \leq 0.05)$ increased SOD and GSH Table (3) and significantly $(\mathrm{P} \leq 0.05)$ decreased MDA Table (3), these finding are in agreement with Kanter et al., (2006) ; Nili-Ahmadabadi et al., (2011). Thymoquinone, has a strong antioxidant effect that inhibite lipid peroxidation, beside the presences of p-cymene, m-cymene, $\alpha$-thujene and carvacrol as a consititeuent of
NS have also very powerful antioxidants activities and free radicals scavenging effects (Burits and Bucar, 2000). Current study show that G4 was significant increase in SOD activity and GSH activity Table (3), these results are in agreement with Mahmoud, (2013), and significant decrease in MDA Table (3), these results are in agreement with Naik et al., (2004) ; Mahmoud, (2013). Curcumin protects the antioxidant enzymes from denaturation as it has strong reactive oxygen species capacity (Madkour, 2012). Masuda et al., (1999) indicated that the antioxidant mechanism of curcumin still unknown, but it may be due to its reaction with glutathione also it turns to dimerization when reacted with free radicals.

G3 was significantly $(\mathrm{P} \leq 0.05)$ decreased in DNA fragmentation after $20 \& 30$ days of experiment Table (3) \& fig. (1), these results are confirmed by El-Barbary, (2008). Where Busby and Wogan, (1984) reported how NS reduce the DNA fragmentation, that in the liver microsomes, AFB1 is oxidized to its reactive epoxide forming exo AFB-8, 9 epoxide. This subsequently links itself to DNA and exhibits the mutagenicity (Lasky and Magder, 1997). AFB1 -DNA adduct disabilities the Nglycosidic bond of nucleotide leading to depurination and DNA strand scission (Lyer et al., 1994), So decreasing the binding formation to the AFB1, excision repair is the 
system which primarily repair DNA-adducts (Sancar and Sancer, 1988). So this system may be activated via antioxidants which catalyse formation of polar, and conjugate between the epoxide intermediate of AFB and glutathione leading to reduce AFB1 -DNA adduction (Koob and Dekant, 1991). G4 was significantly $(\mathrm{P} \leq 0.05)$ decreased in DNA fragmentation when compared to $\mathrm{G} 2$ after $10,20 \& 30$ days of experiment Table (3) \& fig.(1), these results are confirmed by ( Siddique et al., 2010, Madkour, 2012). DNA fragmentation observed in the present study is the normal consequence of oxidative stress that was demonstrated through elevation in LPO, and antioxidant enzymes (GPx, GST and GR) and glutathione content in rat liver (Madkour, 2012). This is also consistent with previous studies where DNA fragmentation was induced by AFs in rat lymphocytes (Sharma et al., 2010). G4 produced low DNA fragmentation, that ensures the supplementation of curcumin to AF quails reduce the DNA fragmentation these results coincide with that of (Siddique et al., 2010) who stated that Curcumin inhibits the generation of ROS that are responsible for the DNA damage. Also, this action of Curcumin was explained by (Piwocka et al., 2001) who stated that Curcumin leaded to attenuated
DNA fragmentation due to the normalization of GSH.

\section{Conclusion:}

Our results indicate that Nigella sativa crushed seeds and Curcumin powder have a protective effect against AF induced immunosuppression and hepatotoxicity in quails.

\section{Acknowledgments:}

The authors are thankful to Dr. Azza A. Hassan. Department of Biochemistry, Animal Health Research Institute (AHRI), Mansoura, Egypt and Dr. Heba M. Abdelrazek. Dept of physiology, faculty of Vet. Medicine, Suez Canal University, Ismailia, Egypt. For their laboratory help.

\section{Reference:}

Abdel-Wahhab, M. A. and Aly, S. E. (2005): Antioxidant property of Nigella sativa (black cumin) and Syzygium aromaticum (clove) in rats during aflatoxicosis. J. Appl. Toxicol. 25 (3), 218- 23.

Abo-Norag, M.; Edrington, S.; Kubena, F.; Harvey, B. and Phillips, D. (1995): Influence of a hydrated sodium calcium aluminosilicate and virginiamycin on aflatoxicosis in broiler chicks. Poult. Sci. 74, 626-632.

Afonso, V.; Champy, R.; Mitrovic, D.; Collin, P. and Lomri, A. (2007): Reactive oxygen species and superoxide dismutases: role in joint diseases. Joint Bone Spine. 74 (4), 324-329. 
Al-Gaby, A. M. (1998): Amino acid composition and biological effect of supplementing broad bean and corn protein with Nigella sativa (Black cumin) cake protein. Nahr. 42 (5), $290-294$.

Al-Ghamdi, M. S. (2001): The anti-inflammatory, analgesic and antipyretic activity of Nigella sativa. Journal of Ethnopharmacology. 76, 45- 48.

Aljabre, S. H.; Randhawa, M. A.; Akhtar, N.; Alakloby, O. M.; Alqurashi, A. M. and Aldossary, A. (2005): Antidermatophyte activity of ether extract of Nigella sativa and its active principle, thymoquinone. Journal of Ethnopharmacology. 101, 116- 119. Amiridumari, H.; Sarir, H.; Afzali, N. and FaniMakki, $O$. (2013): Effects of milk thistle seed against AF B1 in broiler model. Journal of research in medical sciences: the official journal of Isfahan University of Medical Sciences. 18 (9), 786.

Andallu, B. and Varadacharyulu, N. (2003): Antioxidant role of mulberry (Morus indica L. cv. Anantha) leaves in streptozotocindiabetic rats. Clin.Chim.Acta. 338, 3- 10 .

Antony, S.; Kuttan, R. and Kuttan, G. (1999): Imunomodulatory activity of Curcumin. Immunol. Invest. 28, 291- 303.

Asgary, S.; Najafi, S.; Ghannadi, A.; Dashti, G. and Helalat, A. (2012): Efficiency of black cumin seeds on hematological factors in normal and hypercholesterolemic rabbits. ARYA atherosclerosis. 7(4), 146.

Ashiq, S.; Hussain, M. and Ahmad, B. (2014): Natural occurrence of mycotoxins in medicinal plants: a review. Fungal genetics and Biology. 66, 1- 10.

Ayoub, M. M.; El-Far, A. H.; Taha, N. M.; Korshom, M. A.; Mandour, A. A.; Abdel-Hamid, H. S.; and El-Neweshy, M. S. (2011): The biochemical protective role of some herbs against aflatoxicosis in ducklings: II. Nigella sativa. Lucrări ŞtiinţificeUniversitatea de Ştiinţe Agricole şi Medicină Veterinară, Seria Zootehnie. 55, 68- 77.

Bals, R. (2000): Epithelial antimicrobial peptides in host defense against infection. Respir. Res. 1, 141- 150 .

Basmacioglu, G.; Oguz, H.; Ergul, M.; Col, R. and Birdane, Y. O. (2005): Effect of dietary esterified glucomannan on performance, serum biochemistry and haematology in broiler exposed to AF. Czech Journal of Animal Science. 20, 31- 39.

Bennett, J. W. and Klich, M. (2003): Mycotoxins. Clinical Microbiology Review. 16, 497516.

Beutler, E.; Duran, O. and Kelly, B. (1963): improved method for the determination of blood glutathione. J. of lab. And clinic. Med. 61, 882.

Burits, M. and Bucar, F. (2000): Antioxidant activity of Nigella 
sativa essential oil. Phytother. Res. 14, $323-328$.

Busby, W. F. Jr. and Wogan, G. N. (1984): AF. Inc: Scarle, C.E.(ed.). Chemical carcinogens, $2^{\text {nd }}$ ed. ACS Monograph 182 . Washington DC. American Chemical Society. 945- 1136.

Chamanza, R.; van Veen, L.; Tivapasi, M. T. and Toussaint, $M$. J. M. (1999): Acute phase proteins in the domestic fowl. World's Poult. Sci. J. 55, 61- 70.

Choudhary, A. and Verma, R.J. (2005): Ameliorative effect of black tea extract on aflatoxin induced lipid peroxidation in the liver of mice. Food and Chemical Toxicology. 43, 99- 104.

Choy, W. N. (1993): A review of the dose-response induction of DNA adducts by AF $\mathrm{B} 1$ and its implications to quantitative cancerrisk assessment. Mutat. Res. 296, $181-198$.

DAFF. (2013): Structure and dynamics of the quail. Commonwealth of Australia. Department of Agriculture, Editor. 2013.

Devegowda, G.; Raju, M. V. L. N.; Afzali, N. and Swamy, H. V. L. N. (1998): Mycotoxins picture worldwide: Novel solutions for their counteraction. In T.P. Lyons and K.A. Jacques (Eds.) Biotechnology in the Feed Industry, Proc. Of Alltech's 14, the Annual Symp. Nottingham, U.K. 241- 255.

Diaz, M. F.; Gonzalez, A.; Padilla, C. and Curbelo, F. (2002): Bromatological characterization of grains and forages from the seasonal legumes Canavalia ensiformis, Lablab purpureus and Stizolobium niveum at the end of the rainy season. Cuban J. Agric. Sci. 36 (4), 395- 401.

Doumas, B. T. and Biggs, H. G. (1972): Determination of serum globulin. In: standard Methods of Clinical Chemistry. Vol. 7 edited by G.R Copper, New York Academic Press.

El-Agamy, D. S. (2010): Comparative effects of Curcumin and resveratrol on AF B1-induced liver injury in rats. Archives of toxicology. 84(5), 389- 396.

El-Bahr, S. M. (2014): Effect of Curcumin on Hepatic Antioxidant Enzymes Activities and Gene Expressions in Rats Intoxicated with AF B1. Phytotherapy Research. 29 (1), 134- 140.

El-Barbary, M. I. (2008): AF B1 induced-changes in protein electrophoretic pattern and DNA in Oreochromis niloticus with special emphasis on the protective effect of rosemary and parsley extracts. American-Eurasian J. Agric. \& Environ. Sci. 4 (3), 381- 390.

El-Ghammry, A. A.; El-Mallah, G. M. and El-Yamny, A. T. (2002): The effect of incorporation yeast culture, Nigella sativa seeds and fresh garlic in broiler diets on their performance. Egypt. Poult. Sci. 22, 445- 459.

El-Sayed, Y. S. and Khalil, R.H. (2009): Toxicity, biochemical effects and residue of $\mathrm{AF} \mathrm{B} 1$ in marine water reared sea bass 
(Dicentrarchus labrax L.). Food Chem Toxicol. 47, 1606- 1609.

Eraslan, G. O.; Liman, B. C.; Guclu, B. K.; Atasever, A. Y.; Koc, A. N. and Beyaz, L. A. (2004): Evaluation of AF toxicity in Japanese quails given various doses of hydrated sodium calcium aluminosilicate. Bull Vet Inst Pulawy. 48, 511- 517.

Eraslan, G.; Akdogan, M.; Yarsan, E.; Sahindokuyucu, F.; Essiz, D. and Altintas, L. (2005): The effects of AFs on oxidative stress in broiler chickens. Turk. J. Vet. Anim. Sci. 29, 701- 707.

Eshak, M. G.; Deabes, M. M.; Farrag, A. R. H.; Farag, I. M. and Stino, F. K. (2013): Effect of ozone-treated AF contaminated diets on DNA damage, expression of androgen and androgen receptor genes and histopathological changes in Japanese quail. Global Veterinaria. 11(1), 1- 13.

Faridha, A.; Fasial, K. and Akbarsha, M.A. (2006): Durationdependent histopathological and histometric changes in the testis of AF B1-treated mice. J. Endocrinol. Reprod. 10 (2), 117-133.

Ferreira, F. D.; Kemmelmeier, C.; Arrotéia, C. C.; da Costa, C. L.; Mallmann, C. A.; Janeiro, V. and Machinski, M. (2013): Inhibitory effect of the essential oil of Curcuma longa L. and Curcumin on AF production by Aspergillus flavus Link. Food chemistry. 136 (2), 789-793.

Gibb, R. K.; Taylor, D. D.; Wan, T.; O'Connor, D. M.; Doering, D.
L. \& Gerçel-Taylor, Ç. (1997): Apoptosis as a measure of chemosensitivity to cisplatin and taxol therapy in ovarian cancer cell lines.Gynecologic oncology. 65(1), 13-22.

Gowda, N. K. S.; Ledoux, D. R.; Rottinghaus, G. E.; Bermudez, A. J. and Chen, Y. C. (2008): Efficacy of turmeric (Curcuma longa), containing a known level of Curcumin, and a hydrated sodium calcium aluminosilicate to ameliorate the adverse effects of AF in broiler chicks. Poultry science. 87 (6), 1125- 1130.

Hassan, S. M.; Mady, M. E.; Cartwright, A. L.; Sabri, H. M. and Mobarak, M. S. (2003): Effect of early feed restriction on reproductive performance in Japanese quail (Coturnix coturnix japonica). Poult. Sci. 82, 11631169.

Hoyer, J. D. (1993): Laboratory Med and pathology Leucocytic differential count. Mayo Clinic Prossiding. 68, 1027- 1028.

Jindal, N.; Manipal, S. K. and Mahajan, N. K. (1994): Toxicity of AF B1 in broiler chicks and its reduction by activated charcoal. Res. Vet. Sci. 56, 37- 40.

Josephy, P. D. (1997): Molecular Toxicology. Oxford, UK: Oxford Univ. Press.

Kallio, M. and Lahdetie, J. (1997): Effects of the DNA topoisomerase II inhibitor membrane in male mouse meiotic divisions in vivo cell cycle and 
induction of aneuploidy. Environ. Mol. Mutagen. 29, 16- 27.

Kanter, M.; Coskun, O.; Kalayci, M.; Buyukbas, S. and Cagavi, F. (2006): Neuroprotective effects of Nigella sativa on experimental spinal cord injury in rats. Hum. Exp. Toxicol. 25, 127- 133.

Kanter, M.; Demir, H.; Karakaya, C. and Ozbek, $H$. (2005): Gastroprotective activity of Nigella sativa L. oil and its constituent, thymoquinone against acute alcohol-induced gastric mucosal injury in rats. World Journal of Gastroenterology. 11, 6662- 6666.

Karabacak, M.; Eraslan, G.; Kanbur, M. \& Sarica, Z. S. (2015): Effects of Tarantula cubensis D6 on AF-induced injury in biochemical parameters in rats. Homeopathy.

Khan, M. A. U.; Ashfaq, M. K.; Zuberi, H. S.; Mahmood, M. S. and Gilani, A. H. (2003): The in vivo antifungal activity of the aqueous extract from Nigella sativa seeds. Phytotherapy Research. 17 (2), 183- 186.

Koob, M. and Dekant, W. D. (1991): Bioactivation of xenobiotics by formation of toxic glutathione conjugates. Chemico-Biological Interactions. 77, 107- 136.

Lasky, T. and Magder, L. (1997): Hepatocellular carcinoma P53 G > $\mathrm{T}$ transversions at codon 249: the fingerprint of AF exposure. Environmental Health Perspectives. 105, 392- 397.
Le, P. M.; Ali, B.; Aziz, E.; Abdellatif, S.; Yahia, C. and Pierre, S. H. (2004): The petroleum ether extract of Nigella sativa exerts lipid-lowering and insulin-sensitizing actions in the rat. Journal of Ethnopharmacology. 94 (3), 251- 259.

Lee, K. G. and Shibamoto, T. (2001): Antioxidant property of aroma extract isolated from clove buds [Syzygium aromaticum (L.) Merr. et Perry. Food Chemistry. 74 (4), 443- 448.

Lee, K. W.; Everts, H.; Kappert, H. J.; Frehner, M.; Losa, R. and Beynen, A. C. (2003): Effects of dietary essential oil components on growth performance, digestive enzymes and lipid metabolism in female broiler chickens. Br. Poult. Sci. 44, 450- 457.

Lyer, R. S.; Coles, B. F; Raney, K. D.; Their, R.; Guengerich, F.P. and Harris, T. M. (1994): DNA adduction by the potent carcinogen AF B : Mechanistic Studies. J. American Chem. Soc. 116, 16031609.

Madheswaran, R.; Balachandran, C. and Manohar, B. M. (2004): Influence of dietary culture material containing $\mathrm{AF}$ and $\mathrm{T} 2$ toxin on certain serum biochemical constituents in Japanese quail. Mycopath. 158 (3), 337- 341.

Madkour, N. K. (2012): Protective effect of Curcumin on oxidative stress and DNA fragmentation against lambda cyhalothrin-induced liver damage in rats. Journal of 
Applied Pharmaceutical Science (JAPS). 2 (12), 76- 81.

Mahmoud, E. A. (2013): Effect of Curcumin on hematological, biochemical and antioxidants parameters in Schistosoma mansoni infected mice. International Journal of Sciences. 2 (3), 1- 14.

Maraqa, A.; Al- sharo, N. F.; Farah, H.; Elbjeirami, W. M.; Shakya, A. K. and Sallal, A. (2007): Effect of Nigella sativa Extract and Oil on AF Production by Aspergillus flavus J. Turk. J. Biol. 31, 155- 159.

Mariam, G. E; Mohamed, M. D; Abdel Razik; H. F; Ibrahim, M. F. and Farid, K. R. (2013): Effect of Ozone-Treated AF Contaminated Diets on DNA Damage, Expression of Androgen and Androgen Receptor Genes and Histopathological Changes in Japanese quail. Global Vet. 11 (1), 01- 13.

Masuda, T.; Hidaka, K.; Shinohar, A.; Maekawa, T.; Takeda, Y. and Yamaguchi, $H$. (1999): Chemical studies in antioxidant mechanism of Curcuminoids: analysis of radical reaction products from Curcumin. Journal of Agriculture and Food Chemistry. 47, 71- 77.

Mathuria, N. and Verma, R. J. (2008): Ameliorative effect of Curcumin on AF-induced toxicity in serum of mice. Acta. Pol. Pharmaceut. Drug Res. 65, 339343.

Milani, J. M. (2013): Ecological conditions affecting mycotoxin production in cereals: a review. Veterinary Medicine. 58 (8), 405- 411.

Mohamed, S. S.; Mohamed, S. R.; Abou-Arab, A. A.; Naguib, K. M.; Helmy, M. H. and Owiss, N. A. (2014): Comparison study on native olive waste extract and its nanoparticles effect on oxidative stress induced by AF B1 in rat brain. Int. J. Curr. Microbiol. App. Sci. 3 (4), 141- 152.

Mohapatra, S.; Sahu, N. P.; Pal, A. K.; Prusty, A. K.; Kumar, V. and Kumar, S. (2011): Haematoimmunology and histoarchitectural changes in Labeo rohita fingerlings: effect of dietary AF and mould inhibitor. Fish Physiol Biochem 37, 177- 186.

Morsi, N. M. (2000): Antimicrobial effect of crude extracts of Nigella sativa on multiple antibioticsresistant bacteria. Acta Microbio. Polonica. 49, 63- 74.

Murray, R. (1984): Alanine aminotransferase. Clin Chem the C.V mosby Co. St Louis. Toronto.Princeton. 1088- 1090.

Naaz, F.; Javed, S. and Abdin, M. Z. (2007): Hepatoprotective effect of ethanolic extract of Phyllanthus amarus Schum. et Thonn. on AF B 1-induced liver damage in mice. Journal of ethnopharmacology. 113 (3), 503509.

Nabney, J. and Nesbitt, B. F. (1965): A spectrophotometric method for determining the AFs. Analyst. 90 (1068), 155- 160. 
Naik, R. S.; Mujumdar, A. M. and Ghaskadbi, S. (2004): Protection of liver cells from ethanol cytotoxicity by Curcumin in liver slice culture in vitro. Journal of Ethnopharmacology. 95, 31- 37.

Nasir, Z. and Grashorn, M. A. (2010): Effects of Echinacea purpurea and Nigella sativa supplementation on broiler performance, carcass and meat quality. J. Anim. Feed. Sci. 19, 94104.

Natt, M. P. and Herrick, C. A. (1952): A new blood diluents for counting the erythrocytes and leucocytes of chickens. Poultry Sci. 31, 735- 738.

Nazar ， F. N.; Magnoli, A. P.; Dalcero, A. M. and Marin, R. H. (2012): Effect of feed contamination with AF $\mathrm{B} 1$ and administration of exogenous corticosterone on Japanese quail biochemical and immunological parameters. Poultry Science. 91, 47-54.

Nili-Ahmadabadi, A.; Tavakoli, F.; Hasanzadeh, G. R.; Rahimi, H. R. and Sabzevari, O. (2011): Protective effect of pretreatment with thymoquinone against $\mathrm{AF} \mathrm{B} 1$ induced liver toxicity in mice. Daru: journal of Faculty of Pharmacy, Tehran University of Medical Sciences. 19(4), 282.

Nishikimi, M.; Rao, N. A. and Yogi, K. (1972): The occurance of super oxide anion in the reaction of reduced phenazine methosulfate and molecular oxygen. Biochemical and
Biophysical Research. 46, 849 854.

Nostro, A.; Germano, M. P.; D'Angelo, V. and Cannatelli, M. A. (2000): Extraction methods and bioautography for evaluation of medicinal plant antimicrobial activity. Letters in Applied Microbiology. 30, 279- 284.

NRC National Research Council (1994): Nutritional requirements of poultry". 9th Rev. Ed. National academy press, Washington, DC.

Ortatatli, M.; Oğuz, H.; Hatipoğlu, F. and Karaman, M. (2005): Evaluation of pathological changes in broilers during chronic AF $(50$ and $100 \quad \mathrm{ppb})$ and clinoptilolite exposure. Research in Veterinary Science. 78 (1), 61- 68.

Piner, P. and Üner, N. (2012): Oxidative and apoptotic effects of lambdacyhalothrin modulated by piperonyl butoxide in the liver of Oreochromis niloticus. Environ. Toxicol. Pharmacol. 33, 414- 420.

Piwocka, K.; Jaruga, E.; Skierski, J.; Gradzka, I. and Sikora, E. (2001): Effect of glutathione depletion on caspase-3 independent apoptosis pathway induced by Curcumin in Jurkat cells. Free Radic. Biol. Med. 31, 670- 678.

Preetha, S. P.; Kanniappan, M.; Selvakumar, E.; Nagaraj, M. Varalakshmi，P. (2006): Lupeol ameliorates AF B1 induced peroxidative hepatic damage in rats. Comp. Biochem. Physiol. C: Pharmacol. Toxicol. 143, 333-339. Preston, R. J. and Williams, G. M. (2005): DNA- reactive 
carcinogen, mode of action and human cancer hazard. Criterion Rev Toxicol. 35, 673-683.

Rodkey, F. L. (1965): Clin Chem. 11, 478- 487.

Rooney, S. and Ryan, M. F. (2005): Effects of alpha-hederin and thymoquinone - a constituent of Nigella sativa, on human cancer cell lines. Anticancer Research 25, 2199- 2204.

Rosa, C. A. R.; Miazzo, R.; Magnoli, C.; Salvano, M.; Chiacchiera, S. M.; Ferrero, S. and Dalcero, A. (2001): Evaluation of the efficacy of bentonite from the south of Argentina to ameliorate the toxic effects of AF in broilers. Poultry Science. 80 (2), 139- 144.

Sahin, N.; Akdemir, F.; Orhan, C.; Kucuk, O.; Hayirli, A. and Sahin, K. (2008): Lycopeneenriched Quail egg as functional food for humans. Food Research International. 41, 295- 300.

Sahoo, P. K.; Mukherjee, S. C.; Jain, A. K. and Mukherjee, A. (2001): Histopathological and electron microscopic studies of gills and opisthonephros of Rohu, Labeo rohita to acute and subchronic AF B1 toxicity. Asian Fish Sci. 16, 257-268.

Sancar, A. and Sancer, G. B. (1988): DNA repair enzymes. Ann. Rev. Biochem. 57, 29- 67.

Sanchis, V. and Magan, N. (2004): Environmental conditions affecting mycotoxins. Mycotoxins in food: detection and control. 174- 189.
Satoh, K. (1978): Serum lipid peroxide in cerebrovascular disorders determined by a new colorimetric method. Clin. Chim. Acta, 90, 37.

Selim, M.; El-hofy, H. and Khalil, R. (2014): The efficacy of three mycotoxin adsorbents to alleviate AF B1-induced toxicity in Oreochromis niloticus. Aquacult Int. 22, 523-540.

Sharma, D.; Saxena, P.; Singh, V. and Sharma, R. (2010): Assessment of DNA degradation in lymphocytes of albino rat (Rattus norvegicus) under lambda cyhalothrin stress. World Appl. Sci. J. 11(1), 24- 28.

Sharma, V.; Sharma, C.; Paliwal, R.; Pracheta, S. S. and Sharma, S. (2011): Ameliorative effects of Curcuma longa and Curcumin on AF B1 induced serological and biochemical changes in kidney of male mice. Asian J Biochem Pharmaceut Res. 2(1), 338- 351.

Shehata, S. A.; El-Melegy, Kh. M.; Ebrahim M. S. and AbouSeif, R. A. (2009): AF B1 Toxicity Reduction by Tafla Clay, Honey and Nigella Sativa Addition in Fish. Journal of the arabian aquaculture society. 4 (1), 55- 72.

Shishodia, S.; Sethi, G. and Aggarwal, B. B. (2005): Curcumin: Getting Back to the Roots, Annals of the New York Aca- demy of Sci. 1056 (1), 206- 217.

Shotwell, O. L.; Hesseltine, C. W.; Stubblefield, R. D. and Sorenson, W. G. (1966): Production of AF on 
rice. Applied Microbiology. 14 (3), 425- 428.

Siddique, Y.; Ara, G.; Beg, T. and Afzal, M. (2010): Protective effect of Curcumin against chlormadinine acetate induced genotoxic damage in cultured human peripheral blood lymphocytes. Pharmacologyonline. 3, 644- 650 .

Tahan, M. and Bayram, I. (2011): Effect of using black cumin (Nigella sativa) and parsley (Petroselinum crispum) in laying quail diets on egg yield, egg quality and hatchability. Archiva Zootechnica. 14 (4), 39-44.

Tarasub, N.; Junseecha, T.; Tarasub, C. and Ayutthaya, W. D. (2012): Protective effects of Curcumin, vitamin $\mathrm{C}$, or their combination on cadmium-induced hepatotoxicity. Journal of basic and clinical pharmacy. 3 (2), 273.

Trivedi, N. (1999): Effect of radiomimetic plant on vital organ. Ph. D. thesis, Gujarat University, Ahmedabad, India.

Tunsaringkarn,

Tungjaroenchai, W. and Siriwong, W. (2013): Nutrient benefits of Quail (Coturnix coturnix japonica) eggs. International Journal of Scientific and Research publications. 3 (5).
Wang, F.; Shu, G.; Peng, X.; Fang, J.; Chen, K.; Cui, H. and Lai, W. (2013): Protective effects of sodium selenite against AF B1induced oxidative stress and apoptosis in broiler spleen. International journal of environmental research and public health. 10 (7), 2834- 2844.

Williams, J. H.; Phillips, T. D., Jolly P. E.; Stiles, J. K.; Jolly, C.M. and Aggarwal, D. (2004): Human aflatoxicosis in developing countries: A review of toxicology, exposure, potential health consequences and interventions. Am. J. Clin. Nutr. 80, 1106- 1122.

Yamakura, F. and Fujimura, T. H. (1998): Inactivation of manganese superoxide dismutase by peroxynitrite is caused by exclusive nitration of tyrosine 34 to 3 nitrotyrosine. J. Biol. Chem. 273, 14085-14089.

Young, D. S. (1995): Effects of drugs on clinical lab". Tests. $4^{\text {th }}$ ed AACC Press.

Zaki, M. S.; Fawzi, O. M. and Zytuun, I. M. (2011): Reduction of alfatoxin in Clarious lazara catfish by ginseng extract and Nigella sativa oil. Journal of American Science. 7(2), 591- 596. 


\section{الملخص العربي}

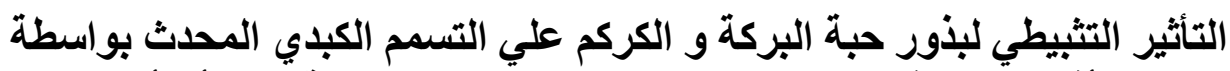

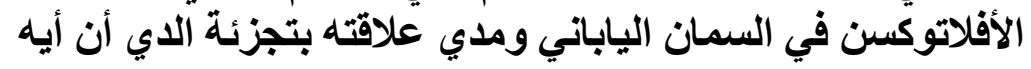

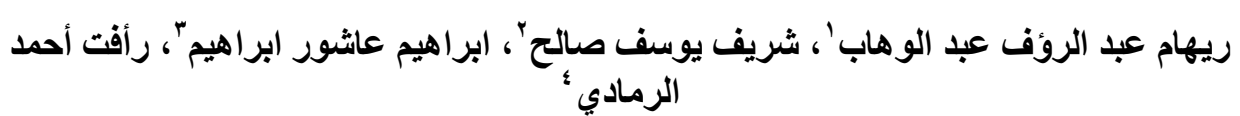

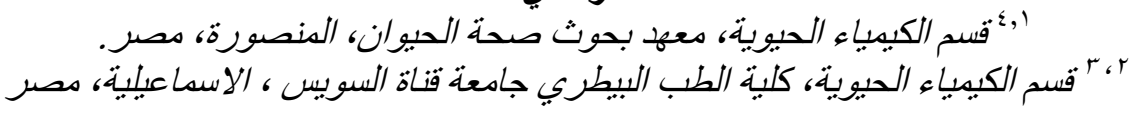

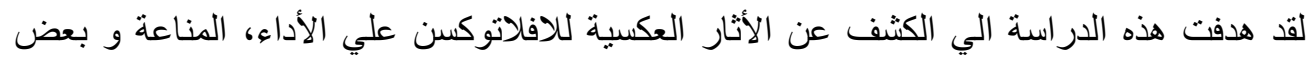

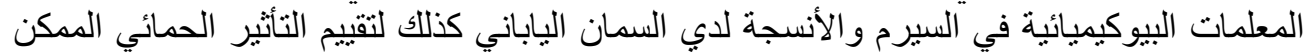

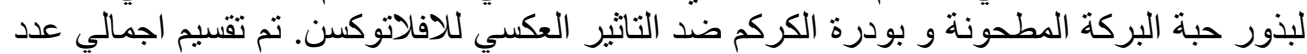

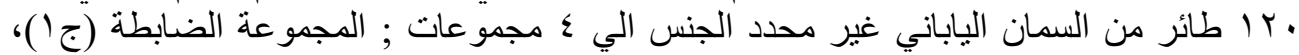

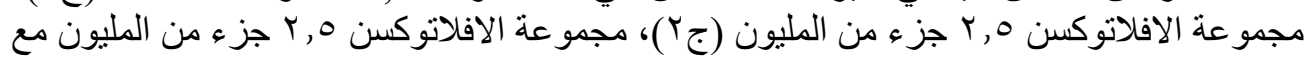

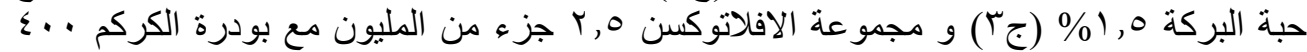

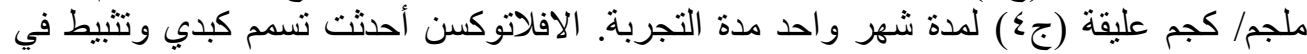

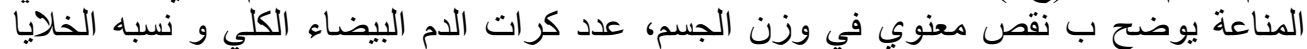

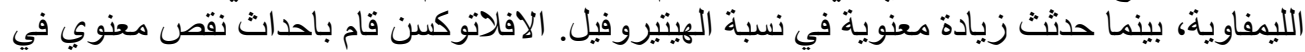

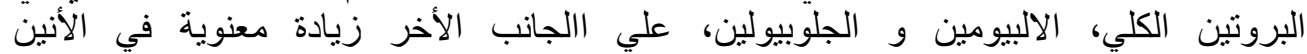

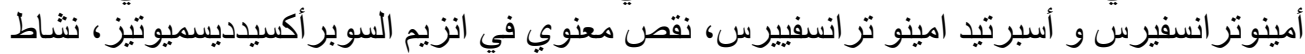

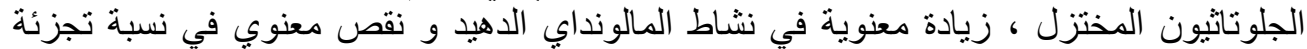

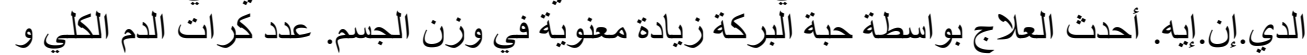

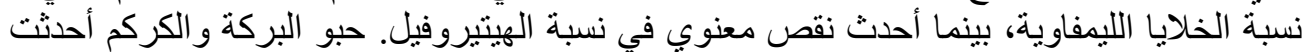

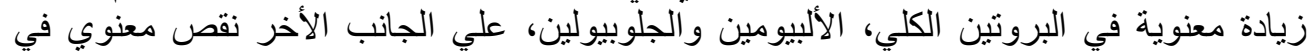

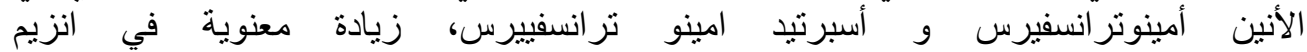

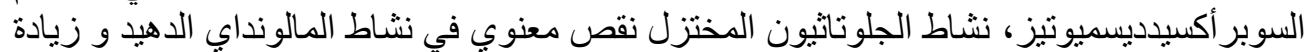

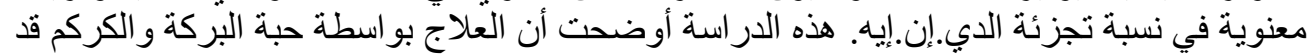

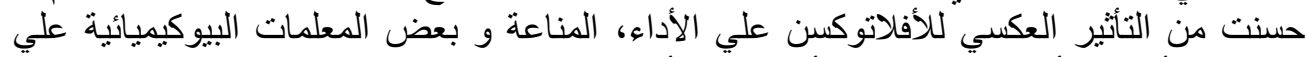

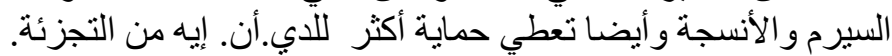

